\title{
QUANTITATIVE ANALYSIS OF ASBESTOS FIBRES IN OPHIOLITIC ROCKS USED AS AGGREGATES AND HAZARD RISK ASSESSMENT FOR HUMAN HEALTH
}

\section{Rigopoulos I. ${ }^{1}$, Tsikouras B. ${ }^{1}$, Pomonis P. ${ }^{2}$, Karipi S. ${ }^{1}$, and Hatzipanagiotou $\mathrm{K}^{1}$}

\footnotetext{
${ }^{1}$ University of Patras, Department of Geology, Section of Earth Materials, 26500 Patras - Greece, rigopoul@upatras.gr,v.tsikouras@upatras.gr,skaripi@upatras.gr,k.hatzipangiotou@upatras.gr

${ }^{2}$ University of Athens, Department of Geology and Geoenvironment, 15784 Athens, Greece, ppomonis@uoa.geol.gr
}

\begin{abstract}
This study focuses on the quantification of asbestiform minerals in basic and ultrabasic rocks from ophiolite suites of central and northern Greece. A combination of different methods were used for the detailed investigation of the samples, conducted in the following stages: (i) petrographic examination of thin sections with a polarizing microscope, (ii) mineral phase analysis using $X$-ray diffraction, (iii) determination of the fibrous mineral composition on polished thin sections using scanning electron microscopy, (iv) image analysis of back-scattered electron images and secondary electron images, to quantify the dangerous asbestiform crystals. SEM is proved to be the most powerful tool for the detailed investigation of fibrous minerals, although polarized microscopy and XRD are necessary tools for a preliminary identification of these minerals.

Basic rocks contain various amounts of actinolite, however not all crystals comprise asbestiform fibres. A conspicuous feature observed during careful petrographic analysis is that many of the nonasbestiform actinolite crystals are broken up along their cleavage planes. Rocks with such features need specific consideration since these crystals may subsequently release numerous fibrous cleavage fragments during the production processes and in-service deterioration of aggregates. Among the serpentinized ultrabasic samples, only one contains chrysotile, while the other samples contain antigorite and lizardite.
\end{abstract}

Key words: asbestos, image analysis, ophiolitic rocks, petrography, scanning electron microscopy, $X$-ray diffraction.

\section{Introduction}

The term asbestos (from the Greek "asbestos"= inextinguishable) is a general commercial-industrial term used to describe a group of naturally occurring silicate minerals of fibrous or asbestiform habit. These minerals can be divided into two basic groups: (i) the serpentines, which include only the asbestiform chrysotile and (ii) the amphiboles, which include the asbestiform varieties of actinolite, tremolite, anthophyllite, crocidolite (riebeckite) and amosite (cummingtonite-grunerite). They have been used since ancient times as raw materials for the production of a large variety of materials and objects due to their exceptional attributes (high tensile strength, flexibility, chemical and heat re- 
sistance). The inherent properties of asbestos fibres appear to contribute to the toxicity of these mineral particles when lodged inside the human respiratory system (Stanton et al., 1981; Wylie et al., 1993). Occupational exposures to asbestos have been linked to asbestosis, lung cancer, malignant mesothelioma and various cancers of digestive tract (Mossman et al., 1990; Nolan et al., 2001; Constantopoulos, 2008; Murray and Nelson, 2008).

Ophiolitic rocks may contain various amounts of asbestos minerals (e.g. Skarpelis and Dabitzias, 1987; Ross and Nolan, 2003; Rigopoulos et al., 2008). Chrysotile is usually the most common of these minerals in ophiolitic rocks, since it is possible to be found in any type of serpentinized ultrabasic rock, either as alteration product of olivine and/or orthopyroxene or as veins crosscutting the rock. Basic ophiolitic rocks may also contain considerable percentages of amphibole asbestos fibres, principally actinolite and/or tremolite, which represent alteration products of clinopyroxene (e.g. Tsikouras et al., 2005; Rigopoulos et al., 2006).

Asbestos fibres are thin, needle-like crystals that may vary widely in diameter within the millimetre to micron range. The biologically more important so-called "critical" fibres are those with the following shape criteria: length $\geq 5 \mu \mathrm{m}$, diameter (width) $\leq 3 \mu \mathrm{m}$ and length to diameter ratio (aspect ratio, AR) $\geq 3: 1$ (World Health Organization, 1986). Asbestos crystals in ophiolitic rocks used as aggregates for road construction, railway ballast, concrete and other applications, are particularly dangerous for public health, since fibres of the above mentioned sizes may be released into the air during in-service deterioration of aggregates, becoming dangerous for public health. In this study, the proportions of asbestiform minerals were determined in basic and ultrabasic rock samples collected from ophiolite suites of central and northern Greece, using a combination of different techniques.

\section{Geological setting}

Sampling was performed to the Guevgueli, Pindos, Vourinos and Koziakas ophiolites, which are among the most well-known ophiolitic complexes of Greece (Fig. 1).

The Guevgueli ophiolite (Mercier, 1966; Bebien, 1982; Ivanov et al., 1987), occupies the northern part of the "Innermost Hellenic Ophiolite Belt" (IMHOB) in Greece. It comprises a parautochthonous, Jurassic complex, comprising gabbroic cumulates, diorites associated with plagiogranites, a hypabyssal sheeted dyke complex and mafic lavas. Sampling was performed to the eastern part of the ophiolite, in a sheeted dyke complex, which includes dolerites and minor gabbros.

The Pindos and Vourinos Jurassic ophiolites belong to the western Greek ophiolitic belt and are thought to be continuous beneath the Cenozoic molasse of the Mesohellenic trough (Jones et al., 1991; Rassios and Smith, 2000). Sampling was performed to the eastern part of the Pindos ophiolite, in a well preserved sheeted dyke complex. This area has been further divided into three subunits, which comprise the following lithologies (Rigopoulos et al., 2010): (i) dolerite and minor gabbro, (ii) dolerite, (iii) pillow lavas and minor dolerite. In the Vourinos complex sampling was focused on a dolerite exposure, located to the western part of the ophiolitic occurrences. Two types of dolerites have been distinguished according to their macroscopic characteristics (Rigopoulos et al., 2010): the first group displays significant amounts of chlorite (dark green-coloured), while the second is characterized by the presence of actinolite in high percentages (pale green-coloured). Serpentinized ultrabasic samples were also collected from the mantle section of the Pindos and Vourinos ophiolites.

The Koziakas Jurassic ophiolite belongs to the western Greek ophiolitic belt and it was probably developed, together with the Pindos, Vourinos and Othris ophiolite suites, in the same marginal basin volcanic arc regime in the Pindos ocean (Pomonis et al., 2005; Pomonis et al., 2007). Sampling was 


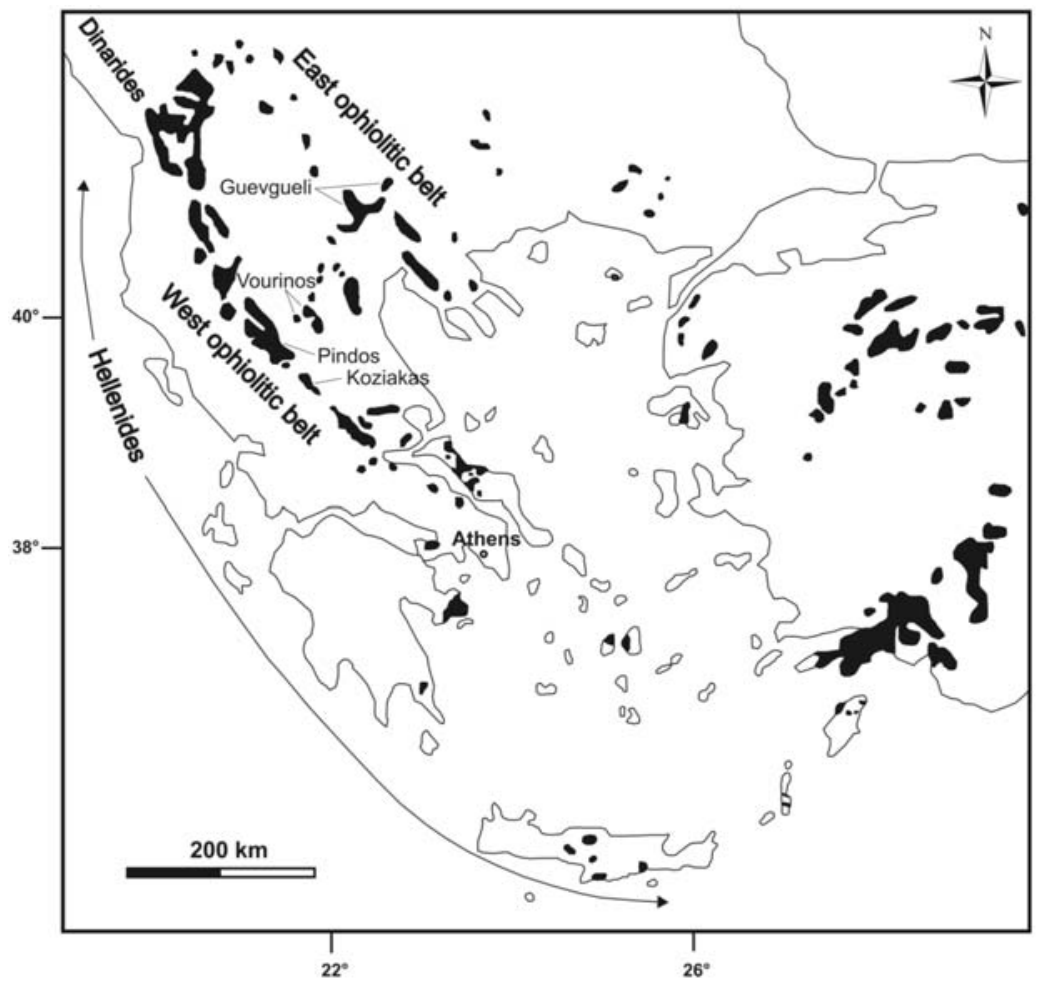

Fig. 1: Simplified map showing the studied areas and the distribution of the ophiolitic outcrops of Greece and neighbouring countries.

performed to the northern part of the ophiolite, which comprises mantle peridotites with various degrees of serpentinization. These are predominantly harzburgites and secondarily plagioclase-bearing lherzolites.

\section{Methods and results}

\subsection{Petrography}

A preliminary qualitative analysis of thin sections with a polarized microscope was first accomplished in order to determine the general mineralogical and textural characteristics of the studied rock types. Quantitative measure of the concentration of the constituent minerals was then carried out using a point-counting system.

\subsubsection{Basic lithotypes}

Dolerites from the Guevgueli, Pindos and Vourinos ophiolites are fine-grained isotropic rocks with subophitic texture (Fig. 2a). Laths of subhedral plagioclase and interstitial anhedral clinopyroxene of augite composition comprise the subophitic groundmass. They are in general equigranular rocks but locally become porphyritic, with subhedral to euhedral plagioclase and clinopyroxene phenocrysts set in a fine-grained matrix with subophitic texture (Fig. 2b). Opaque minerals include various percentages of magnetite, pyrite and chalcopyrite. Titanite is also present in small amounts. Secondary products are actinolite, chlorite, quartz, epidote and clinozoisite. Actinolite and chlorite 

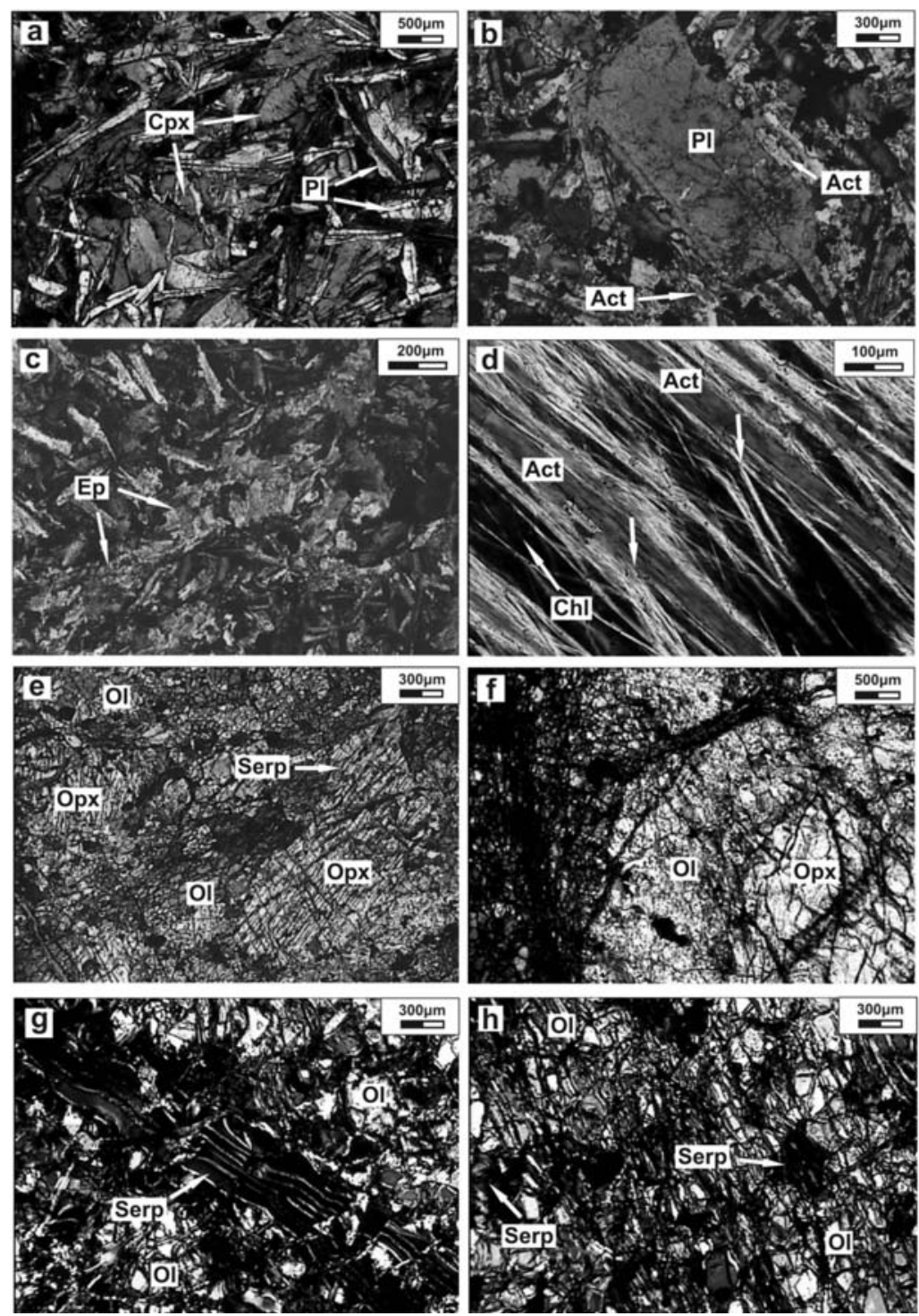

Fig. 2: Photomicrographs (XPL) of the studied basic rocks: a) dolerite with typical subophitic texture (sample PVN2a), b) plagioclase phenocryst in a fine-grained matrix with subophitic texture (sample G1), c) vein filled with epidote (sample B4), d) actinolite crystals broken up along their cleavage planes (arrows indicate characteristic fractures - sample PVN1b). Photomicrographs (XPL) of the studied ultrabasic rocks: e,f) cataclastic and porphyroclastic texture in serpentinized harzburgites (samples VVDSR1 and KOZ2, respectively), g) ribbon texture and $\mathrm{h}$ ) preferred orientation of olivine grains in serpentinized harzburgites (sample PKZSR1), (Pl: plagioclase, Cpx: clinopyroxene, Act: actinolite, Chl: chlorite, Ol: olivine, Opx: orthopyroxene, Serp: serpentine).

represent alteration products of clinopyroxene. Actinolite is found either as short prismatic or as fibrous, asbestiform crystals. Epidote and clinozoisite are detected as fine-grained alteration products in saussuritized plagioclase and quartz crystals usually occupy spaces between the other grains, however these minerals also fill veins crosscutting the rock (Fig. 2c). Additionally, calcite commonly fills veins in the Guevgueli and Vourinos dolerites. Another feature observed during the pet- 
Table 1. Mineralogical composition (in vol\%) of the studied basic rocks (Pl: plagioclase, Cpx: clinopyroxene, Act: actinolite, Chl: chlorite, Qz: quartz, Ep: epidote, Cc: calcite, Op: opaque minerals).

\begin{tabular}{|l|c|c|c|c|c|c|c|c|}
\hline Sample code/locality & $\boldsymbol{P l}$ & $\boldsymbol{C p x}$ & $\boldsymbol{A c t}$ & $\boldsymbol{C h l}$ & $\boldsymbol{Q z}$ & $\boldsymbol{E p}$ & $\boldsymbol{C c}$ & $\boldsymbol{O p}$ \\
\hline *G1/Guevgueli & 44.3 & 15.6 & 11.9 & 12.4 & 1.9 & 7.1 & 1.4 & 5.4 \\
\hline Ｇ2/Guevgueli & 48.6 & 32.7 & 10.8 & 3.6 & 0.4 & 1.9 & 1.2 & 0.8 \\
\hline *PVN1a/Pindos & 47.7 & 13.7 & 23.3 & 4.3 & 7.7 & 1.3 & - & 2.0 \\
\hline *PVN1b/Pindos & 49.3 & 15.3 & 21.0 & 3.0 & 7.0 & 1.7 & - & 2.7 \\
\hline *PVN2a/Pindos & 50.7 & 38.0 & 0.3 & 7.3 & 1.0 & 0.7 & - & 2.0 \\
\hline *PVN2b/Pindos & 46.7 & 36.0 & 2.0 & 10.3 & 0.7 & 2.0 & - & 2.3 \\
\hline *B4/Vourinos & 48.8 & 2.3 & 5.6 & 17.0 & 11.3 & 7.1 & 3.3 & 4.6 \\
\hline *B5/Vourinos & 51.8 & 3.7 & 26.1 & 1.8 & 3.5 & 7.6 & 2.1 & 3.4 \\
\hline
\end{tabular}

(*: dolerite, $\sim$ : gabbro)

Table 2. Mineralogical composition (in vol\%) of the studied ultrabasic rocks (Ol: olivine, Opx: orthopyroxene, Cpx: clinopyroxene, Pl: plagioclase, Sp: spinel, Serp: serpentine, Ox: oxides, Tc: talc, Chl: chlorite, $\mathrm{Tr} /$ Act: tremolite/actinolite, Cc: calcite).

\begin{tabular}{|l|c|c|c|c|c|c|c|c|c|c|c|}
\hline Sample code/locality & $\boldsymbol{O l}$ & $\boldsymbol{O p x}$ & $\boldsymbol{C p x}$ & $\boldsymbol{P l}$ & $\boldsymbol{S p}$ & Serp & $\boldsymbol{O} \boldsymbol{x}$ & $\boldsymbol{T c}$ & $\boldsymbol{C h l}$ & $\boldsymbol{T r} / \mathbf{A c t}$ & $\boldsymbol{C c}$ \\
\hline *PKZSR1/Pindos & 35.5 & 4.5 & 0.5 & - & 0.5 & 47.5 & 8.5 & 0.5 & 1.5 & 0.5 & 0.5 \\
\hline *VVDSR1/Vourinos & 39.0 & 12.5 & - & - & 1.0 & 38.0 & 9.0 & - & - & - & 0.5 \\
\hline$\sim$ KOZ1/Koziakas & 41.5 & 10.5 & 4.0 & 1.0 & 1.0 & 28.5 & 3.0 & 1.5 & 1.5 & 7.5 & - \\
\hline *KOZ2/Koziakas & 47.0 & 16.0 & - & - & 1.0 & 30.5 & 2.5 & 2.0 & 1.0 & - & - \\
\hline
\end{tabular}

(*harzburgite, $\sim$ : plagioclase-bearing lherzolite)

Table 3. Mineral phases detected in the investigated rock samples using X-ray diffraction (Chl: chlorite, Act: actinolite, Pl: plagioclase, Aug: augite, Qz: quartz, Ep: epidote, Cc: calcite, Mt: magnetite, Tit: titanite, Lz: lizardite, Ant: antigorite, Chry: chrysotile, Fo: forsterite, En: enstatite, Di: diopside, Sp: spinel).

\begin{tabular}{|l|l|}
\hline Sample code/locality & Mineralogical composition \\
\hline G1/Guevgueli & Chl, Act, Pl, Aug, Qz, Ep, Mt \\
\hline G2/Guevgueli & Chl, Act, Pl, Aug, Qz, Ep, Cc, Tit \\
\hline PVN1a/Pindos & Chl, Act, Pl, Aug, Qz, Ep, Mt \\
\hline PVN1b/Pindos & Chl, Act, Pl, Aug, Qz, Ep, Mt \\
\hline PVN2a/Pindos & Chl, Pl, Aug, Qz, Ep, Mt \\
\hline PVN2b/Pindos & Chl, Act, Pl, Aug, Qz, Ep, Mt \\
\hline B4/Vourinos & Chl, Act, Pl, Aug, Qz, Ep, Cc, Mt \\
\hline B5/Vourinos & $\mathrm{Chl,} \mathrm{Act,} \mathrm{Pl,} \mathrm{Qz,} \mathrm{Ep,} \mathrm{Cc,} \mathrm{Mt}$ \\
\hline PKZSR1/Pindos & Lz, Ant, Fo, En, Sp, Mt \\
\hline VVDSR1/Vourinos & $\mathrm{Lz}$, Ant, Fo, En, Mt \\
\hline KOZ1/Koziakas & Lz, Ant, Chry, Fo, En, Act, Di, Sp \\
\hline KOZ2/Koziakas & Lz, Ant, Fo, En, Sp \\
\hline
\end{tabular}


rographic analysis, is that many of the actinolite crystals are broken up along their cleavage planes (Fig. 2d). The percentages of the mineral phases are shown in Table 1.

Regarding the gabbroic rocks collected from the Guevgueli ophiolite suite, they have subhedral to anhedral granular to ophitic texture, most commonly medium- to coarse-grained. Their primary and secondary mineral phases are the same as those of the studied dolerites (Table 1).

\subsubsection{Ultrabasic lithotypes}

The studied ultrabasic rocks from the Pindos, Vourinos and Koziakas ophiolites include harzburgites with various degrees of serpentinization and deformation. A sample of plagioclase-bearing lherzolite was also collected from the Koziakas mantle section. These rock types mainly display cataclastic and locally porphyroclastic texture (Figs 2e,f). The primary mineralogy of the harzburgites comprises olivine, orthopyroxene (enstatite) with exsolution lamellae of clinopyroxene (diopside) and disseminated spinel (Table 2). The plagioclase-bearing lherzolites also contain clinopyroxene (diopside) and interstitial plagioclase (bytownite-anorthite). Olivine and orthopyroxene occur both as porphyroclasts and neoblasts. Due to hydrothermal alteration, the primary minerals are transformed into secondary products (olivine into hydrated associations of serpentine minerals, orthopyroxene mainly into bastite and talc, clinopyroxene into actinolite, tremolite and chlorite, and spinel into ferrian chromite and magnetite). Some of the samples are crosscut by veins of calcite. The areas occupied by serpentine usually display pseudomorphic mesh and ribbon textures (Fig. 2g) (O'Hanley, 1996). Evidence of plastic deformation is shown in strained olivine and orthopyroxene porphyroclasts, which display well-developed undulatory extinction and kink-bands. Intense deformation results locally in a preferred orientation of the olivine grains (Fig. 2h).

\subsection{X-Ray Diffraction}

$\mathrm{X}$-ray diffraction (XRD) is a widely used analytical technique for identifying minerals and characterizing their crystal structure. It is generally a semi-quantitative method, although it is possible to estimate the amounts of minerals present in a rock using complicated special procedures (Snyder and Bish, 1989; Addison and Davies, 1990; Williams-Jones et al., 2001).

In the present study, XRD was performed on powdered samples in order to determine asbestos minerals. The weight percent of every mineral in a sample must typically be present in at least 2-3\% to be detected. Asbestos minerals (actinolite and serpentine in basic and ultrabasic samples respectively) were detected in almost all samples (except for the dolerite PVN2a). Regarding the ultrabasic lithotypes, chrysotile was detected only in the plagioclase-bearing lherzolite (see Table 3).

\subsection{Scanning Electron Microscopy}

Scanning Electron Microscope (SEM) is of particular value in identifying asbestiform minerals, since it allows much greater magnifications than polarized microscope and also allows semi-quantitative or quantitative chemical analysis of the imaged material. Hence, it is feasible to analyse and record the length and diameter of individual fibres in any rock type. Elemental analysis of individual separated fibres is ordinarily semi-quantitative but is often sufficient for mineral identification.

Standard analytical methods for quantitative analysis of asbestos have been difficult to develop, primarily due to the difficulty in standardizing the many operating parameters that are controlled in SEM (Clinkenbeard et al., 2002). However, in this study the following procedure is proposed for the quantification of asbestiform crystals: 
$\mathrm{Ca}_{\|}>1.50,(\mathrm{Na}+\mathrm{K})_{\mathrm{A}}<0.50, \mathrm{Ca}_{\Lambda}<0.50$

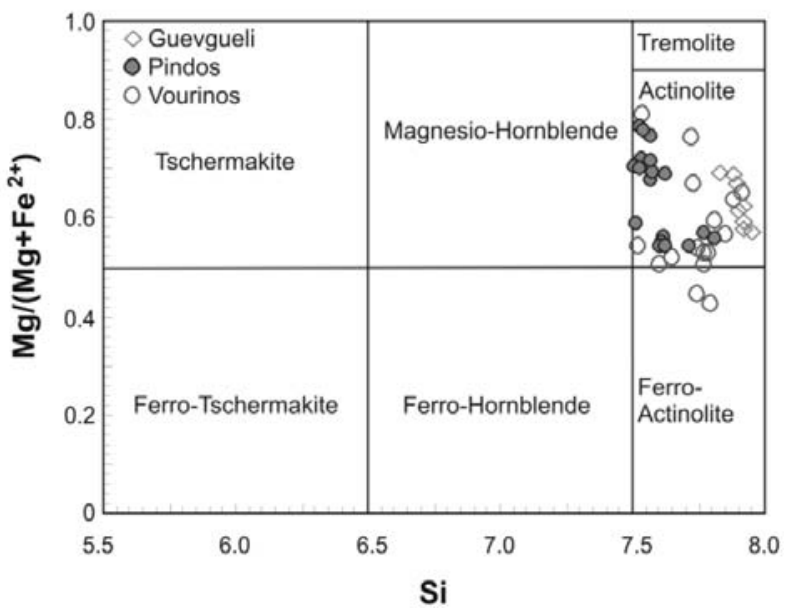

Fig. 3: Plot of the analyzed amphibole crystals from the studied basic rocks on their classification diagram (after Leake et al., 1997).

- Elemental analysis of the constituent minerals - identification of the asbestiform mineral phases.

- Imaging of the studied polished thin sections at several magnifications, depending on the grain size of each lithotype (the images are equally distributed on each thin section). In this study, two polished thin sections were investigated for each sample and six back-scattered electron (BSEI) or secondary electron (SEI) images were acquired from each one.

- Measurement of the dimensions (length and diameter) of the fibrous and non-fibrous crystals which belong to the group of asbestos minerals. The images were analysed using the Leica QWin image analysis software.

- The measurements are statistically analyzed. This process includes: (i) discrimination of the dangerous asbestiform crystals, which fulfil the shape criteria referred to the introduction, (ii) calculation of the area occupied by the dangerous asbestiform crystals, (iii) calculation of the total percentage (vol\%) of the dangerous asbestiform crystals.

- Representative compositions of amphibole and serpentine from the investigated basic and ultrabasic samples are listed in Table 4. According to the classification of Leake et al. (1997), the analyzed amphiboles from the Pindos, Vourinos and Guevgueli basic igneous rocks are actinolite (Fig. 3). In the ultrabasic samples, chrysotile is not feasible to be detected by elemental analysis due to its similar chemical composition with the other polymorphs of serpentine (antigorite and lizardite).

The back-scattered electron images (BSEI) acquired for the basic igneous rocks indicated that actinolite participates in various percentages. Among the collected rocks, samples B5, PVN1a, PVN1b, G1 and G2 contain the highest percentages of actinolite, which is detected in various sizes. One generation of larger crystals comprises non-asbestiform, short prismatic crystals and represents the main percentage of actinolite (Fig. 4a-c). Locally, a second generation of asbestiform crystals is present (Fig. 4b-d). It is also mentioned that specific areas of the polished thin sections are totally 
Table 4. Representative microanalyses of (a) amphiboles and (b) serpentines from the studied basic and ultrabasic samples (-: below detection limit).

\begin{tabular}{|c|c|c|c|c|c|c|c|c|}
\hline Sample & G1 & G2 & PVN1a & PVN1b & PVN2a & PVN2b & B4 & B5 \\
\hline Analysis & 1 & 12 & 17 & 11 & 26 & 30 & 19 & 32 \\
\hline $\mathrm{SiO}_{2}$ & 55.90 & 55.70 & 52.45 & 52.03 & 52.97 & 52.79 & 54.02 & 55.79 \\
\hline $\mathrm{TiO}_{2}$ & - & - & - & - & - & - & - & 0.04 \\
\hline $\mathrm{Al}_{2} \mathrm{O}_{3}$ & 3.47 & 3.45 & 5.43 & 2.81 & 2.35 & 1.78 & 2.79 & 3.51 \\
\hline $\mathrm{FeO}^{\mathrm{t}}$ & 14.25 & 15.90 & 16.46 & 25.03 & 10.56 & 14.89 & 15.75 & 15.80 \\
\hline $\mathrm{MnO}$ & - & - & - & 0.65 & - & 0.72 & 0.67 & - \\
\hline $\mathrm{MgO}$ & 13.54 & 11.87 & 11.23 & 8.81 & 13.13 & 10.61 & 12.12 & 12.30 \\
\hline $\mathrm{CaO}$ & 11.11 & 11.84 & 11.79 & 8.96 & 19.80 & 16.45 & 10.43 & 9.68 \\
\hline $\mathrm{Na}_{2} \mathrm{O}$ & - & - & 0.73 & - & - & - & - & 0.52 \\
\hline $\mathrm{K}_{2} \mathrm{O}$ & - & - & - & - & - & - & 0.43 & - \\
\hline $\mathrm{Cr}_{2} \mathrm{O}_{3}$ & - & - & - & - & - & - & - & 0.25 \\
\hline Total & 98.27 & 98.76 & 98.09 & 98.29 & 98.81 & 97.24 & 96.21 & 97.89 \\
\hline
\end{tabular}

Structural formulae on the basis of $23 \mathrm{O}$ and cat. sum-Ca-Na-K=13

\begin{tabular}{|c|c|c|c|c|c|c|c|c|}
\hline $\mathrm{Si}$ & 7.890 & 7.950 & 7.618 & 7.519 & 7.628 & 7.822 & 7.880 & 7.909 \\
\hline $\mathrm{Al} \mathrm{IV}$ & 0.110 & 0.050 & 0.382 & 0.479 & 0.372 & 0.178 & 0.120 & 0.091 \\
\hline $\mathrm{Fe}^{3+}$ & - & - & - & 0.002 & - & - & - & - \\
\hline $\mathrm{Ti}$ & - & - & - & - & - & - & - & - \\
\hline & 8.000 & 8.000 & 8.000 & 8.000 & 8.000 & 8.000 & 8.000 & 8.000 \\
\hline $\mathrm{Al}^{\mathrm{VI}}$ & 0.470 & 0.530 & 0.548 & - & 0.027 & 0.133 & 0.360 & 0.495 \\
\hline $\mathrm{Ti}$ & - & - & - & - & - & - & - & 0.004 \\
\hline $\mathrm{Fe}^{3+}$ & 0.280 & - & - & 1.706 & - & - & 0.419 & 0.479 \\
\hline $\mathrm{Cr}$ & - & - & - & - & - & - & - & 0.027 \\
\hline $\mathrm{Mg}$ & 2.850 & 2.530 & 2.432 & 1.898 & 2.819 & 2.344 & 2.636 & 2.600 \\
\hline $\mathrm{Fe}{ }^{2+}$ & 1.400 & 1.900 & 1.999 & 1.316 & 1.272 & 1.845 & 1.502 & 1.395 \\
\hline $\mathrm{Mn}$ & - & - & - & 0.080 & - & 0.090 & 0.083 & - \\
\hline & 5.000 & 4.950 & 4.979 & 5.000 & 4.117 & 4.411 & 5.000 & 5.000 \\
\hline $\mathrm{Mg}$ & - & - & - & - & - & - & - & - \\
\hline $\mathrm{Fe}$ & - & - & - & - & - & - & - & - \\
\hline $\mathrm{Mn}$ & - & - & - & - & - & - & - & - \\
\hline $\mathrm{Ca}$ & 1.680 & 1.810 & 1.835 & 1.387 & 2.000 & 2.000 & 1.630 & 1.470 \\
\hline $\mathrm{Na}$ & - & - & 0.165 & - & - & - & - & 0.143 \\
\hline & 1.680 & 1.810 & 2.000 & 1.387 & 2.000 & 2.000 & 1.630 & 1.613 \\
\hline $\mathrm{Ca}$ & - & - & - & - & 1.055 & 0.611 & - & - \\
\hline $\mathrm{Na}$ & - & - & 0.040 & - & - & - & - & - \\
\hline $\mathrm{K}$ & - & - & - & - & - & - & 0.038 & - \\
\hline & - & - & 0.040 & - & 1.055 & 0.611 & 0.038 & - \\
\hline
\end{tabular}


Table 4 continued.

b.

\begin{tabular}{|c|c|c|c|c|}
\hline Sample & PKZSR1 & VVDSR1 & KOZ1 & KOZ2 \\
\hline Analysis & 15 & 10 & 14 & 1 \\
\hline $\mathrm{SiO}_{2}$ & 39.55 & 40.63 & 38.26 & 41.41 \\
\hline $\mathrm{TiO}_{2}$ & - & - & 0.05 & - \\
\hline $\mathrm{Al}_{2} \mathrm{O}_{3}$ & 1.45 & - & 3.58 & 1.06 \\
\hline $\mathrm{Fe}_{2} \mathrm{O}^{3 \mathrm{t}}$ & 6.23 & 2.05 & 6.61 & 4.28 \\
\hline $\mathrm{MnO}$ & 0.11 & 0.04 & - & 0.06 \\
\hline $\mathrm{MgO}$ & 39.22 & 38.45 & 34.77 & 38.01 \\
\hline $\mathrm{CaO}$ & - & 0.08 & 0.03 & - \\
\hline $\mathrm{NiO}$ & - & - & - & 0.3 \\
\hline $\mathrm{Cr}_{2} \mathrm{O}_{3}$ & 0.17 & - & - & 0.14 \\
\hline Total & 86.73 & 81.25 & 83.30 & 85.26 \\
\hline \multicolumn{5}{|c|}{ Structural formulae on the basis of 280} \\
\hline $\mathrm{Si}$ & 7.510 & 8.068 & 7.531 & 7.907 \\
\hline $\mathrm{Ti}$ & - & - & 0.008 & - \\
\hline $\mathrm{Al}$ & 0.324 & - & 0.830 & 0.239 \\
\hline $\mathrm{Fe}^{3+}$ & 0.890 & 0.306 & 0.979 & 0.615 \\
\hline $\mathrm{Fe}^{2+}$ & - & - & - & - \\
\hline $\mathrm{Mn}$ & 0.018 & 0.007 & - & 0.010 \\
\hline $\mathrm{Mg}$ & 11.102 & 11.382 & 10.203 & 10.819 \\
\hline $\mathrm{Ca}$ & - & 0.017 & 0.007 & - \\
\hline $\mathrm{Ni}$ & - & - & - & 0.046 \\
\hline $\mathrm{Cr}$ & 0.026 & - & - & 0.021 \\
\hline
\end{tabular}

Table 5. Content of asbestiform actinolite crystals in the studied basic ophiolitic rocks (in vol\%).

\begin{tabular}{|l|c|l|c|}
\hline Sample code/locality & $\begin{array}{l}\text { Asbestiform } \\
\text { actinolite (vol\%) }\end{array}$ & $\begin{array}{l}\text { Sample } \\
\text { code/locality }\end{array}$ & $\begin{array}{l}\text { Asbestiform } \\
\text { actinolite (vol\%) }\end{array}$ \\
\hline G1/Guevgueli & 0.10 & G1/Guevgueli & 0.04 \\
\hline G2/Guevgueli & 0.05 & G2/Guevgueli & 0.07 \\
\hline PVN1a/Pindos & 1.58 & PVN1a/Pindos & 0.12 \\
\hline PVN1b/Pindos & 1.44 & PVN1b/Pindos & 0.97 \\
\hline
\end{tabular}

consist of dangerous, asbestiform crystals (Figs $4 \mathrm{e}$ f). The percentages of the latter were calculated according to the procedure described above (Table 5).

All peridotite samples of this study contain significant amounts of serpentine, however only the plagioclase-bearing lherzolite contains fibrous chrysotile. These crystals become identifiable only in 

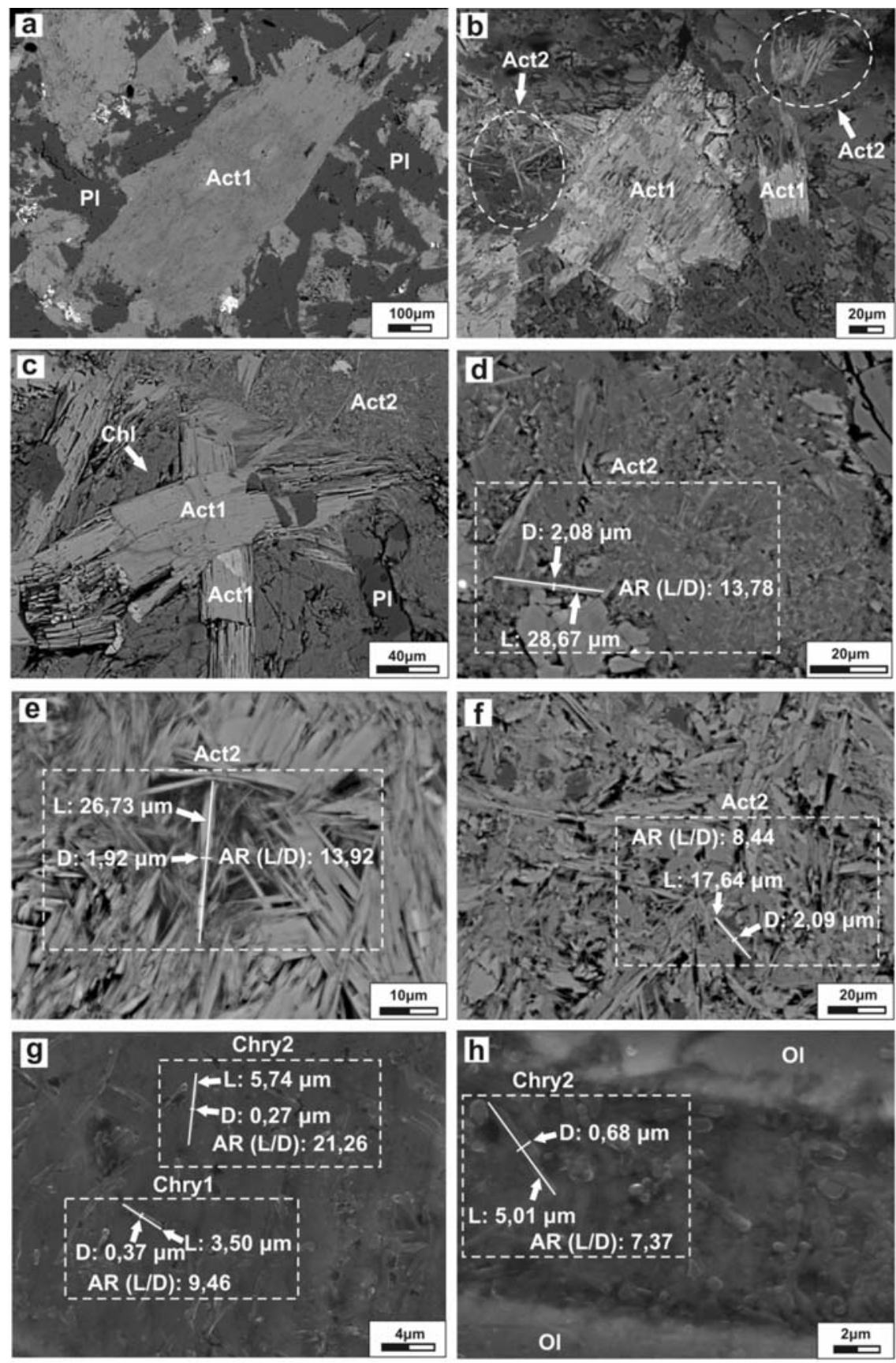

Fig. 4: Back-scattered electron images showing: a) short prismatic crystals of actinolite (sample B5), b,c) asbestiform and non-asbestiform actinolite crystals (samples PVN1a and G1, respectively), d) an area with significant percentage of asbestiform actinolite (sample B5) and e,f) areas totally consisting of dangerous, asbestiform crystals (samples PVN1b and B5, respectively), (Act1: non-asbestiform and Act2: asbestiform actinolite crystals). Secondary electron images showing: g) a whole area and h) a vein occupied by asbestiform chrysotile (sample KOZ1), (Chry1: non-asbestiform and Chry2: asbestiform chrysotile crystals). 
secondary electron images (SEI) and they are detected either in areas occupied totally by serpentine (Fig. 4g) or in veins crosscutting the rock (Fig. 4h). The calculated percentage of the dangerous asbestiform crystals of chrysotile in sample KOZ1 is $0.69 \mathrm{vol} \%$.

\section{Discussion}

Various methods have been proposed for the quantification of asbestos minerals (e.g. Plater et al., 1992; Schneider et al., 1998). In this study, a combination of different methods is proposed for the detailed investigation of basic and ultrabasic ophiolitic rocks used as aggregates.

Polarized light microscopy (PLM) is the most familiar analytical technique to geologists, however it considerably limits the lower limit of visibility of asbestos fibres. This method offers the ability to generally differentiate the non-asbestiform and asbestiform habits of a mineral (Clinkenbeard et al., 2002). Using PLM, two types of actinolite crystals were detected in basic rocks according to their crystal habit: asbestiform and non-asbestiform; however the percentage of the measured dangerous fibres maybe underestimated, due to the existence of extremely fine, undetectable crystals. A conspicuous feature observed during careful petrographic analysis is that many of the non-asbestiform actinolite crystals are broken up along their cleavage planes. Rocks with such features need specific consideration, since these crystals may subsequently release numerous fibrous fragments during the production processes and in-service deterioration of aggregates (Rigopoulos et al., 2008). These cleavage fragments may have a similar microscopic appearance to that of true asbestos fibres. On the other hand, the potential existence of chrysotile in the ultrabasic samples was not possible to be designated. This is in consistence with Schneider et al. (1998), who noted that PLM is unreliable for materials containing chrysotile. In this study, a quantitative measure of the total percentage of actinolite and serpentine in each sample was carried out using the point-counting procedure. This technique provides relatively accurate and precise estimates of the asbestos concentration (Perkins, 1990). However, it should be mentioned that although the total percentage of actinolite is a major determinant for the potential danger of basic ophiolitic rocks used as aggregates, the total amount of serpentine in ultrabasic rocks is not considered to be of great importance. In the latter case, XRD and SEM analyses are required in order to investigate the potential existence of asbestiform chrysotile.

XRD can be used to determine the mineral phases that are present in a sample; however it provides no information about their crystal habit (Clinkenbeard et al., 2002). The dimensions of the fibres of asbestos minerals is the main factor of health hazard, hence XRD patterns are not diagnostic for the quantification of fibrous crystals. However, this method is useful for the determination of the asbestos mineral type. In the present study, the XRD method indicated the presence of actinolite in basic rocks. Among the ultrabasic samples, only the plagioclase-bearing lherzolite contains chrysotile, while the other samples contain antigorite and lizardite.

SEM allows imaging and identification of much smaller fibres than PLM and it can be used to evaluate both the morphological and chemical composition of asbestiform minerals. Unlike PLM, the ability of the SEM to utilize reflected energy for imaging, allows fibres adhering to other mineral surfaces to be easily observed. The asbestiform crystals are clearly identifiable since high magnifications can be obtained. However, there is much difficulty in obtaining adequate images of unit fibrils (Clinkenbeard et al., 2002). In this paper, a simplified procedure is proposed for the quantification of asbestiform crystals. BSEI or SEI images, depending on the mineral type, were acquired and analyzed using an image analysing system. The fibres of chrysotile in the ultrabasic samples are identifiable only in SEI images. Statistical analyses of measurements of length, diameter and aspect ratio of asbestos minerals led to the calculation of the amount of crystals with asbestiform habit occur- 
ring in the investigated ophiolitic rocks. As already mentioned, the investigated basic lithotypes contain various amounts of actinolite, while among the ultrabasic samples only the plagioclase-bearing lherzolite contains chrysotile. Nevertheless, none of these samples contains asbestiform crystals over $1.6 \mathrm{vol} \%$. In terms of chrysotile, it is mentioned that its chemical composition is similar with that of antigorite and lizardite, thus it is obvious that chemical analysis by SEM may not be sufficient for distinguishing the different polymorphs of serpentine. This discrimination is possible to be made by determining the crystal structure. Although SEM analysis does not allow determination of crystal structure, this information has been acquired using XRD.

\section{Conclusions}

Due to the possible adverse health effects of asbestos containing rocks used for construction purposes, standardized procedures are required for determining low levels of asbestos in raw materials. The method proposed in this paper is a combination of different techniques and is based on the investigation of various samples of basic and ultrabasic rocks from the Guevgueli, Pindos, Vourinos and Koziakas ophiolites.

The low cost and widely available PLM analysis is very useful for a preliminary identification of asbestos minerals. The quantitative analysis of the mineralogical composition indicated that the basic lithotypes contain various amounts of asbestiform and non-asbestiform actinolite crystals. A noticeable feature observed during the petrographic analysis is that many of the non-asbestiform actinolite crystals are broken up along their cleavage planes. This feature indicates that short prismatic actinolite crystals may subsequently release numerous fibrous fragments during the production processes and in-service deterioration of aggregates. In the ultrabasic samples, which contain various amounts of serpentine, the potential existence of chrysotile was not possible to be designated. Using XRD, it was found that only the plagioclase-bearing lherzolite contains chrysotile. This method also verified the presence of actinolite in basic rocks.

A simplified method was proposed for the quantification of asbestiform crystals using SEM. During this procedure, BSEI or SEI images were acquired and analyzed using an image analysing system. The fibres of chrysotile in the ultrabasic samples are identifiable only in SEI images. Statistical analyses of measurements of length, diameter and aspect ratio of asbestos minerals led to the calculation of the amount of crystals with asbestiform habit occurring in the investigated ophiolitic rocks. The studied basic lithotypes contain variable proportions of actinolite, while among the ultrabasic samples only the plagioclase-bearing lherzolite contains chrysotile. However, none of the collected rocks contains asbestiform crystals over $1.6 \mathrm{vol} \%$.

Considering the advantages and disadvantages of all the methods used in this study, it becomes clear that the image analysis of SEM images is the most powerful tool for quantifying asbestos, although polarized microscopy and XRD are necessary tools for a preliminary identification of these minerals.

\section{Ackowledgements}

We thank the European Social Fund (ESF), Operational Program for Educational and Vocational Training II (EPEAEK II), and particularly the Program PYTHAGORAS, for funding the above work.

\section{References}

Addison, J., and Davies, L.S.T., 1990. Analysis of amphibole asbestos in chrysotile and other minerals. 
Annals of Occupational Hygiene, 34, 159-175.

Bebien, J., 1982. L' association ignee de Guevgueli (Macedoine Greque). Expression d' un magmatisme ophiolitique dans une dechirure continentale. These d' Etat, Univ. Nancy 467pp.

Clinkenbeard, J.P., Churchill, R.K., and Lee, K., 2002. Guidelines for geologic investigations of naturally occurring asbestos in California. California Department of Conservation, California Geological Survey Special Publication 124.

Constantopoulos, S.H., 2008. Environmental mesothelioma associated with tremolite asbestos: Lessons from the experiences of Turkey, Greece, Corsica, New Caledonia and Cyprus. Regulatory Toxicology and Pharmacology, 52(1), 110-115.

Ivanov, T., Misar, Z., Bowes, D.R., Dudek, A., Dumurdzanov, N., Jaros, J., Jelinek, E., and Pacesova, M., 1987. The Demir Kapija-Gevgelija ophiolite massif, Macedonia, Yugolsavia. Ophioliti, 12, 457-478.

Jones, G., Robertson, A.H.F., and Cann, J.R., 1991. Genesis and emplacement of the supra-subduction zone Pindos ophiolite, northwestern Greece. In: Tj Peters et al. (Eds), Ophiolite Genesis and Evolution of the Oceanic Lithosphere, 771-799.

Leake, B.E., Wooley, A.R., Arps, C.E.S., Birch, W.D., Gilbert, M.C., Grice, J.D., Hawthorne, F.C., Kato, A., Kisch, H.J., Krivovichev, V.G., Linthout, K., Laird, J., Mandarino, J., Maresch, W.V., Nickel, E.H., Rock, N.M.S., Scumacher, J.C., Smith, D.C., Stephenson, N.C.N., Ungaretti, L., Whittaker, E.J.W., and Youzhi, G., 1997. Nomenclature of amphiboles; report of the Subcommittee on amphiboles of the International Mineralogical Association, Commission on New Minerals and Mineral Names. American Mineralogist, 82, 1019-1037.

Mercier, J.L., 1966. Sur l'existence et l'age de deux phases regionales du metamorphism alpin dans les zones internes des Hellenides en Macedoine centrale (Grece). Bull.Soc. Geol.France, 8, 1020-1049.

Mossman, B.T., Bignon, J., Corn, M., Seaton, A., and Gee, J.B.L., 1990. Asbestos: scientific developments and implications for public policy. Science, 247, 294-301.

Murray, J., and Nelson, G., 2008. Health effects of amosite mining and milling in South Africa. Regulatory Toxicology and Pharmacology, 52(1), 75-81.

Nolan, R.P., Langer, A.M., Ross, M., Wicks, F.J., and Martin, R.F., 2001. The health effects of chrysotile asbestos: contribution of science to risk-management decisions. The Canadian Mineralogist Special Publication 5, 304pp.

O'Hanley, D.S., 1996. Serpentinites: Records of Tectonic and Petrological History. Oxford University Press, New York, 277pp.

Perkins, R.L., 1990. Point-counting technique for friable asbestos-containing materials. Microscope, 38, 29-39.

Plater, S.F., Riley, R.D., and Simon, S.D., 1992. The classification of asbestos fibres by scanning electron microscopy and computer digitizing tablet. Annals of Occupational Hygiene, 36(2), 155-171.

Pomonis, P., Tsikouras, B., and Hatzipanagiotou, K., 2005. Geological evolution of the Koziakas ophiolitic complex (western Thessaly, Greece). Ofioliti, 30(2), 77-86.

Pomonis, P., Tsikouras, B., and Hatzipanagiotou, K., 2007. Petrogenetic evolution of the Koziakas ophiolite complex (W. Thessaly, Greece). Mineralogy and Petrology, 89, 77-111.

Rassios, A., and Smith, A.G., 2000. Constraints on the formation and emplacement age of western Greece ophiolites (Vourinos, Pindos and Othris) inferred from deformation structures in peridotites. In: Dilek Y, Moores EM, Elthon D, Nicolas A (Eds), Ophiolites and ocean crust: new insights from field studies and the Ocean Drilling Program, Geol.Soc. Am. Spec. Pap., 349, 473-483.

Rigopoulos, I., Pomonis, P., Tsikouras, B., and Hatzipanagiotou, K., 2006. Comparative evaluation of dolerites from the Pindos and Vourinos ophiolitic rocks for their use as aggregates. Tech.Chron. Sci. 
J. TCG $I, 3,49-61$.

Rigopoulos, I., Tsikouras, B., Pomonis, P., and Hatzipanagiotou, K., 2010. The influence of alteration on the engineering properties of dolerites: The examples from the Pindos and Vourinos ophiolites (northern Greece). International Journal of Rock Mechanics \& Mining Sciences 47, 69-80.

Rigopoulos, I., Tsikouras, B., Pomonis, P., Karipi, S., and Hatzipanagiotou, K., 2008. Quantification methods of asbestos fibres in ophiolitic rocks used as aggregates and hazard risk assessment for human health. $26^{\text {th }}$ European Conference of the Society of Environmental Geochemistry and Health, SEGH 2008, Athens, Hellas, 31/3/2008-2/4/2008, Abstracts, 48.

Ross, M., and Nolan, R.P., 2003. History of asbestos discovery and use and asbestos-related disease in context with the occurrence of asbestos within ophiolite complexes. Geological Society of America, Special Paper 373, 447-470.

Schneider, T., Davies, L.S.T., Burdett, G., Tempelman, J., Puledda, S., Jørgensen, O., Buchanan, D., and Paoletti, L., 1998. Development of a method for the determination of low contents of asbestos fibres in bulk material. Analyst, June 1998, 123, 1393-1400.

Skarpelis, N., and Dabitzias, S., 1987. The chrysotile asbestos deposit at Zidani, northern Greece. Ofioliti, 12(2), 403-410.

Snyder, R.L., and Bish, D.L., 1989. Quantitative Analysis, in Bish, D.L. and Post, J.E., eds., Modern Powder Diffraction, Reviews in Mineralogy, Washington, D.C., Mineralogical Society of America, 20, 101-144.

Stanton, M.F., Layard, M., Tegeris, A., Miller, E., May, M., Morgan, E., and Smith, A., 1981. Relation of particle dimensions to carcinogenicity in amphibole asbestoses and other fibrous minerals. J National Cancer Institute, 67, 965-975.

Tsikouras, B., Pomonis, P., Rigopoulos, I., and Hatzipanagiotou, K., 2005. Investigation for the suitability of basic ophiolitic rocks from the Mikroklissoura Grevena area as anti-skid aggregate material and railroad ballast. Proc. of the $2^{\text {nd }}$ Conference of the Committee of Economical Geology, Mineralogy and Geochemistry, 347-356.

Williams-Jones, A.E., Normand, C., Clark, J.R., Vali, H., Martin, R.F., Dufresne, A., and Nayebzadeh, A., 2001. Controls of amphibole formation in chrysotile deposits: evidence from the Jeffrey Mine, Asbestos, Quebec. In: Noland, R.P., Langer, A.M., Ross, M., Wicks, F.J. and Martin, R.F. (Eds), The health effects of chrysotile asbestos: Contribution of science to risk-management decisions, The Canadian Mineralogist, Special Publication 5, Part 2, Exposure to commercial chrysotile - mineralogy, modern products and exposures, 89-104.

World Health Organization, 1986. Asbestos and other natural mineral fibres. Environmental Health Criteria, No. 53. Geneva.

Wylie, A.G., Bailey, K.F., Kelse, J.W., and Lee, R.J., 1993. The importance of width in asbestos fiber carcinogenicity and its implications for public policy. American Industrial Hygiene Association J, $54,239-252$. 